\title{
Ile jest we współczesnej polszczyźnie czasowników dwuaspektowych?
}

Słowa klucze: aspekt czasownikowy, czasowniki dwuaspektowe, kryteria identyfikacji

Czasowników będących jednocześnie dokonanymi i niedokonanymi jest we współczesnej polszczyźnie bardzo niewiele. Poniżej podajemy wszystkie określone jako takie w Słowniku języka polskiego PWN pod redakcja M. Szymczaka: abdykować, adaptować, adoptować, amputować, aresztować, awansować, ciqć (np. 'szablą, ale nie 'papier na strzępy'), deportować, derogować, domicylować, dymisjonować, ejakulować, ekranizować, ekshumować, eksmitować, ekspatriować, eksplodować, ekstradować, erygować, habilitować, imigrować, implodować, importować, inaugurować, inscenizować, inseminować, internować, izolować (w znaczeniu 'odosabniać', nie 'wydzielać'), jawić się, jodować, kanonizować, kapitulować, koronować, mianować, naturalizować, nostryfikować, notyfikować, optować, parafować, pasować (np. 'na rycerza', ale nie w znaczeniu 'rezygnować'), potrafić, ranić, ratyfikować, razić (np. o piorunie), reaktywować, recypować, refinansować, rekultywować, relegować, renegocjować, repatriować, repetować (np. 'klasę', ale nie 'broń'), reprywatyzować, restytuować, retransmitować, rewalidować, rewaloryzować, rewindykować, rewizytować, rewokować, sekularyzować, sekwestrować, separować, stać (tylko w nieosobowym użyciu w czasie 
przeszłym jak w zdaniu nie stało chleba), subskrybować, substytuować, suspendować, tchnać (?), transplantować, transponować, urlopować, uzurpować, wydatkować.

Jak widać, na 73 czasowniki czysto polskie są jedynie ciać, mianować, potrafić, ranić, razić, stać, tchnać i wydatkować (razem osiem), choć większość użytkowników uznałaby za swojskie również koronować i urlopować. Przeważająca większość jest wyraźnie obcego pochodzenia, często skrajnie erudycyjnego lub technicznego, jak derogować, erygować czy sekwestrować.

Pytanie, czy wszystkie wymienione czasowniki zostały zaklasyfikowane właściwie i czy są to wszystkie czasowniki dwuaspektowe występujące we współczesnym języku polskim. Sprawdzenie rzeczywistej dwuaspektowości w niektórych wypadkach nie jest takie proste.

Wydawałoby się, że sprawa jest oczywista i że wystarczy jedno proste kryterium morfologiczne. Mianowicie tylko czasowniki niedokonane tworzą imiesłów przysłówkowy współczesny na -qce, a tylko dokonane imiesłów przysłówkowy uprzedni na -wszy/-tszy. Zatem jeżeli badany czasownik tworzy i jeden, i drugi imiesłów, musi być dwuaspektowy, np. wydatkujqc, wydatkowawszy. Jest tu jednak jeden problem: imiesłowy przysłówkowe, a zwłaszcza uprzedni, są rzadko używane w języku mówionym, przez co użytkownik nie ma wyczucia, czy utworzona forma jest poprawna, bo najczęściej ani nigdy sam jej nie użył, ani nigdy się z nią nie zetknął. Zadając pytanie, czy poprawne są formy potrafiwszy ${ }^{1}$, importowawszy, urlopowawszy (a wszystko to są formy od czasowników często używanych), otrzymywałem w równej mniej więcej proporcji odpowiedzi „tak”, „nie”, „,nie wiem” oraz ,jakieś one dziwne”.

Prostsza jest sprawa, gdy czasownik jest często używany i przechodni. Jak wiadomo, czasowniki niedokonane tworzą czas przyszły wyłącznie analitycznie z czasownikiem posiłkowym być, jedynie dokonane zaś mają formę strony biernej z zostać. Jeżeli zatem badany czasownik może utworzyć czas przyszły z być oraz stronę bierną z zostać, jest on na pewno dwuaspektowy. Na przykład będzie mianowaćl-at i został mianowany. W zakresie użycia tych form każdy rodzimy użytkownik ma doskonałe wyczucie, gdyż stosuje je na co dzień. Gorzej, gdy czasownik jest tak rzadki, że mówiący zwyczajnie nie wie, czy utworzone formy są właściwe, a więc czy można powiedzieć

1 Słowniki poprawnej polszczyzny nie zalecają skądinąd stosowania tej formy. 
zarówno został derogowany, jak i będzie derogowat. Czy ten czasownik ma stronę bierną? I co on dokładnie znaczy i w jakich kontekstach może być użyty? Czy przypadkiem nie można utworzyć od niego odpowiedniej formy na pewno dokonanej w rodzaju zderogować, zaderogować czy wyderogować? Jest to w jakimś sensie wiedza tajemna, dostępna niewielu. Pozostaje tu tylko wierzyć klasyfikacji przedstawionej przez autora słownika.

Jeszcze trudniejsza jest sprawa z czasownikami nieprzechodnimi. O ile stwierdzenie, że jest on niedokonany, jest proste - poprzez sprawdzenie, czy tworzy czas przyszły z być, a także na przykład, czy łączy się z czasownikami kończyć, skończyć, zaczać, zaczynać, które łączą się wyłącznie z dokonanymi, o tyle weryfikacja jego dokonaności jest skomplikowana. Należy znaleźć kontekst, w którym możliwe są jedynie perfectiva, i sprawdzić, czy w takim kontekście może pojawić się badany czasownik. Pytanie, czy taki kontekst w ogóle istnieje. Dobrym kandydatem wydawał się przyimek $w$ wprowadzający okoliczniki czasu, w opozycji do przez: robił to przez chwile / zrobit to w jednej chwili, golit się przez minutę / ogolit się w minu$t e^{2}$. Niestety, okazuje się, że przez łączy się też z niedokonanymi komunikującymi krótką duratywność jak pobawić się, pospacerować, a ponadto pewne czasowniki, jak zaszczekać, zamrugać, polizać nie łączą się normalnie ani $\mathrm{z} w$, ani z przez $^{3}$. Innym niezłym kandydatem wydawały się początkowo spójniki zanim, nagle i wtem, a także test na łączliwość ze zdołać. Mówi się zanim skończysz, zadzwoń; zanim to powiesz, zastanów się; nagle zachorował; wtem pojawit się silny wiatr; nie zdołał tego dokończyć, niemożliwe są natomiast zdania *zanim kończysz, zadzwoń; *zanim to mówisz, zastanów się; *nagle padat deszcz; *wtem wybuchat pożar; nie zdołał kończyć arty$k u \nmid u$. Jednak i w tym wypadku okazało się, że możliwe jest łączenie zanim, nagle i wtem $\mathrm{z}$ niedokonanymi, jak w zdaniach nie podejmuj się tego, zanim nie będziesz wszystkiego wiedziat; za każdym razem, gdy nagle zjawiat sie gość, otwierat butelkę nalewki; jedzie sobie spokojnie, a wtem wpada w poślizg. Również - jak sprawdziłem - akceptowalne jest zdanie nie zdołał tam być na czas. Tak czy owak są to jedne z lepszych kontekstów testujących dokonaność. Jednak - ponieważ akceptowalne są zdania w rodzaju zanim bę-

2 Muszą to być konstrukcje bez dodatkowych określników, akceptowalne jest bowiem zdanie Zwykle golit się w minutę.

3 Wyjątkową konstrukcją jest zdanie typu Polizat lody przez chwile i z obrzydzeniem wyrzucit do kosza. 
dziesz wszystko umiał, nieźle się natrudzisz - nie jest to poszukiwany ideał. Bliska tego ideału jest konstrukcja $A$ wtedy jak nie..., chyba dopuszczająca tylko i wyłącznie perfectiva, np. A wtedy jak się nie odwinie..., A wtedy jak się nie zamachnie i nie skoczy... Oczywiście należy pamiętać, że są dwa rodzaje a wtedy jak nie, graficznie homonimiczne. Pierwszy, właśnie przytoczony, charakteryzuje się tym, że nie nie jest w nim negacją czasownika, jak jest silnie akcentowane dynamicznie (tzw. akcent $d$ 'insistance), a czasownik - formalnie w czasie przyszłym - oznacza czynność przeszłą. Drugi kontekst nie ma wymienionych właściwości, np.: A wtedy jak nie będziesz trenowat, nigdy nie będziesz mistrzem ${ }^{4}$. Są one, mimo formalnej identyczności składników leksykalnych, chyba łatwe do odróżnienia. Jedyny problem polega na tym, że połączenia z niektórymi czasownikami pierwszej konstrukcji a wtedy jak nie są semantycznie komiczne, choć chyba ciągle są akceptowalne, np. A wtedy jak się nie habilituje lub $A$ wtedy jak nie ratyfikuja tego traktatu. Tak czy owak nic lepszego od a wtedy jak nie nie ma.

Przyjmując wskazane wyżej konteksty testujące (dla przechodnich strona bierna z zostać i czas przyszły analityczny; dla nieprzechodnich łączliwość z a wtedy jak nie i czas przyszły analityczny), przystąpiliśmy do weryfikacji czasowników z listy Szymczaka. Pominęliśmy najbardziej uczone, niewystępujące w słownictwie ludzi nawet bardzo starannie wykształconych, a więc: derogować, domicylować, ekspatriować, ekstradować, erygować, implodować, jodować, recypować, rewalidować, rewokować, sekularyzować, sekwestrować, substytuować, suspendować, transponować. Wszystkie pozostałe, jak się wydaje, są znane, przynajmniej biernie, osobom z wyższym wykształceniem humanistycznym. Z weryfikacji tej wynika, że z całą pewnością dwuaspektowe są czasowniki: abdykować, adaptować, adoptować, amputować, aresztować, awansować, ciać, deportować, dymisjonować, ejakulować, ekranizować, ekshumować, eksmitować, inaugurować, internować, izolować, kanonizować, koronować, mianować, naturalizować, nostryfikować, notyfikować, optować, parafować, pasować, ranić, ratyfikować, razić, reaktywować, refinansować, rekultywować, relegować, renegocjować, repatriować, repetować, reprywatyzować, restytuować, retransmitować, rewaloryzować, transplantować, urlopować, uzurpować, wydatkować.

\footnotetext{
${ }^{4} \mathrm{Na}$ istnienie tego kontekstu zwróciła mi uwagę prof. G. Habrajska.
} 
W celu sprawdzenia przeprowadzono króciutką ankietę wśród pięciu osób, wszystkie z wyższym wykształceniem humanistycznym. Każda z nich jednomyślnie zaakceptowała wymienione wyżej czasowniki jako dwuaspektowe (podane im zostały użycia w kontekstach). Pewne wątpliwości budził czasownik inaugurować w kontekście został inaugurowany. Wszyscy stwierdzili, że lepiej brzmi został zainaugurowany, ale ostatecznie wszyscy zgodzili się, że konstrukcja zostat inaugurowany też jest akceptowalna. Dowodzi to, że dwuaspektowość jest w jakimś stopniu stopniowalna. Problem z inaugurować polega na tym, że w znaczeniu perfektywnym ma dublet wyłącznie dokonany w postaci zainaugurować. Taki dublet ma też aresztować-zaaresztować, adaptować-zaadaptować, adoptować-zaadoptować, eksmitować - wyeksmitować, inseminować - zainseminować, jednak dwuaspektowość form bezprzedrostkowych w wypadku tych ostatnich nie budziła wątpliwości. Komentarze wywołała forma został raniony, a mianowicie, że jest to książkowe lub literackie - w języku potocznym powie się zostat zraniony. Najwięcej kontrowersji wzbudziły czasowniki uzurpować i ekranizować, jednak w końcu wszyscy zgodzili się, że $A$ wtedy jak nie uzurpuje sobie..., a także zostat ekranizowany „ostatecznie można powiedzieć”. Z kolei wszyscy ankietowani, bez wyjątku, stwierdzili, że wyłącznie niedokonane są dymisjonować (niedokonane zdymisjonować), importować (niedokonane zaimportować), jawić się (brak odpowiednika dokonanego), potrafić (brak odpowiednika dokonanego), separować (dokonane odseparować). Jednomyślne protesty wzbudziła konstrukcja został separowany oraz a wtedy jak sie nie jawi, jak nie potrafi... Jawić się jest też trudno akceptowalny w pomocniczych kontekstach wskazujących na czasowniki niedokonane jak gdy tylko, zaledwie, zanim. Wydaje się (hipoteza robocza), że jawić się i potrafić były dwuaspektowe, ale przestały nimi być we współczesnej polszczyźnie, natomiast separować został jako taki zaklasyfikowany przez pomyłkę.

Podzielone głosy były jedynie przy czasowniku tchnać. Nikt nie miał wątpliwości, że jest on dokonany, szczególnie w zdaniu tchnąt w niego $d u$ cha. Natomiast wątpliwości wystąpiły przy pytaniu „,czy mówi się będzie tchnat?". Głosy podzieliły się: dwa - tak, dwa - nie, jeden - nie wiem.

Zupełną bezradność okazali wszyscy przy próbie weryfikacji aspektu czasownika stać, w znaczeniu, w którym obecnie występuje jedynie w zaprzeczonej formie nieosobowej czasu przeszłego nie stało (czasu, chleba, pieniędzy itp.). Nieużywanie tej formy w kontekstach, w jakich badane były 
inne czasowniki, powoduje, że nie ma żadnego sposobu, aby sprawdzić jej faktyczną aspektowość.

Podjęta też została próba znalezienia użyć badanych czasowników w Internecie. Forma potrafiwszy miała w sieci 406 wystąpień, w tym niektóre zupełnie „dobrze brzmiące”, szczególnie we frazach poetyckich, jak Nie potrafiwszy gwiazd na niebie zliczyć. Choć - zauważmy - dobrze brzmiące były tylko formy z negacją. Zdawałoby się, że jest to jednak dowód na również dokonaność czasownika potrafić. Jednak okazało się, że forma umiawszy miała 4460 wystąpień, co by wskazywało, że umieć ${ }^{5}$ jest, w użyciu, bardziej dokonane niż potrafić.

Z kolei jako dwuaspektowe zostały jednomyślnie uznane czasowniki nie występujące jako takie w słowniku Szymczaka, a mianowicie: delegować (mimo istnienia oddelegować i wydelegować), doktoryzować (a zwłaszcza doktoryzować się), reanimować, resocjalizować (mimo istnienia zresocjalizować), subsydiować i transferować.

Wydaje się zatem, że we współczesnej polszczyźnie istnieje kilka kategorii czasowników dwuaspektowych: 1) nie budzące wątpliwości; 2) funkcjonujące jako takie tylko w stylach specjalnych (książkowych, poetyckich, archaizujących); 3) zaklasyfikowane arbitralnie, czyli czasowniki dwuaspektowe uznaniowo (z powodu braku wyczucia użytkowników, spowodowanego nieznajomością znaczenia lub wyjątkową rzadkością występowania); 4) budzące wątpliwości; 5) których przynależności aspektowej nie można w żaden sposób rozstrzygnąć (a więc być może dwuaspektowe).

\section{Bibliografia}

Awdiejew A., Habrajska G., 2004-2006, Wprowadzenie do gramatyki komunikacyj$n e j$, t. 1-2, Łask: Oficyna Wydawnicza Leksem.

BogusŁawski A., 2004, Aspekt i negacja, Warszawa: Wydawnictwo Takt.

DyszaK A. S., 2001, Rzeczowniki i czasowniki defektywne w systemie fleksyjnym współczesnej polszczyzny, Biuletyn Polskiego Towarzystwa Językoznawczego LVII, s. 141-154.

${ }_{5} \mathrm{~Np}$. Znajduje się takich wielu, którzy nie umiawszy anatomii ani filozofii naturalnej nie rozumiawszy..., albo Nie umiawszy musiała w rannym umrzeć lecie (Kochanowski). Prawdą jest, że statystykę nie umiawszy zawyża archaiczny cytat z Kochanowskiego. 
Holvoet A., 1989, Aspekt a modalność w języku polskim na tle ogólnosłowiańskim, Wrocław: Ossolineum.

Karolak S., 1996, O semantyce aspektu (w dwudziestą rocznicę publikacji rozprawy F. Antinucciego i L. Gebert „Semantyka aspektu czasownikowego”), Biuletyn Polskiego Towarzystwa Językoznawczego LII, s. 9-56.

Kiparsky P., Kiparsky C., 1970, Fact, w: M. Bierwisch, K. Heidolph (red.), Progress in Linguistics, The Hague: Mouton, s. 143-173.

KuryŁowicz J., Miejsce aspektu w systemie koniugacyjnym, w: Symbolae polonicae in honorem Stanislai Jodlowski, Prace Komisji Językoznawstwa 32, Wrocław: Zakład Narodowy im. Ossolińskich, s. 93-98.

Padučeva E. V., 1998, On non-compatibility of partitive and imperfective in Russian, w: H. Schnelle (red.), Theoretical Linguistics 24, Berlin-New York: Walter de Gruyter, s. 73-82.

ŚMIECH W., 1971, Funkcje aspektów czasownikowych we współczesnym języku ogólnopolskim, Łódź: Zakład Narodowy im. Ossolińskich.

Wierzbicka A., 1967, On the Semantics of the Verbal Aspects in Polish, w: To Honour Roman Jakobson III, The Hague-Paris: Mouton, s. 2231-2249.

WŁodARczy K H., 1997, L'aspect verbal dans le contexte en polonais et en russe, Paris: Institut d'Etudes Slaves.

\section{How many bi-aspectual verbs are there in modern Polish?}

\section{( s u m mary)}

A small number of Polish verbs are bi-aspectual, i.e. they can be either perfective or imperfective. Most of them are of foreign origin and have a specific technical or scientific usage, although some verbs in this group are quite common. It is not always easy to detect bi-aspectual verbs because they do not appear in all possible contexts or they are so rare that even native speakers have doubts about their correct usage. The aim of the present paper is to establish the actual number of bi-aspectual verbs in modern Polish, as well as to discover the criteria of identification of such verbs. 